\title{
In vitro differentiation of endometrial regenerative cells into smooth muscle cells: A potential approach for the management of pelvic organ prolapse
}

\author{
XIUHUI CHEN ${ }^{1}$, XIANCHAO KONG $^{1}$, DONGZHE LIU ${ }^{2}$, PENG GAO $^{3}$, \\ YANHUA ZHANG ${ }^{1}$, PEILING LI ${ }^{1}$ and MEIMEI LIU ${ }^{1}$ \\ ${ }^{1}$ Department of Obstetrics and Gynecology, The Second Affiliated Hospital of Harbin Medical University; \\ ${ }^{2}$ Department of Oncology, The Fourth Affiliated Hospital of Harbin Medical University; \\ ${ }^{3}$ Department of Surgery, Harbin Children's Hospital, Harbin, Heilongjiang 150001, P.R. China
}

Received October 22, 2015; Accepted May 5, 2016

DOI: $10.3892 / \mathrm{ijmm} .2016 .2593$

\begin{abstract}
Pelvic organ prolapse (POP), is a common condition in parous women. Synthetic mesh was once considered to be the standard of care; however, the use of synthetic mesh is limited by severe complications, thus creating a need for novel approaches. The application of cell-based therapy with stem cells may be an ideal alternative, and specifically for vaginal prolapse. Abnormalities in vaginal smooth muscle (SM) play a role in the pathogenesis of POP, indicating that smooth muscle cells (SMCs) may be a potential therapeutic target. Endometrial regenerative cells (ERCs) are an easily accessible, readily available source of adult stem cells. In the present study, ERCs were obtained from human menstrual blood, and phase contrast microscopy and flow cytometry were performed to characterize the morphology and phenotype of the ERCs. SMC differentiation was induced by a transforming growth factor $\beta 1$-based medium, and the induction conditions were optimized. We defined the SMC characteristics of the induced cells with regard to morphology and marker expression using transmission electron microscopy, western blot analysis, immunocytofluorescence and RT-PCR. Examining the expression of the components of the Smad pathway and phosphorylated Smad 2 and Smad 3 by western blot analysis, RT-PCR and quantitative PCR demonstrated that the 'TGFBR2/ALK5/Smad2 and Smad3' pathway is involved, and both Smad2 and Smad3
\end{abstract}

Correspondence to: Dr Peiling Li or Dr Meimei Liu, Department of Obstetrics and Gynecology, The Second Affiliated Hospital of Harbin Medical University, 246 Xuefu Road, Nangang, Harbin, Heilongjiang 150001, P.R. China

E-mail: pllihmu@yahoo.com

E-mail:28607248@qq.com

Key words: endometrial regenerative cell, smooth muscle cell, differentiation, transforming growth factor $\beta 1$, pelvic organ prolapse, cell-based therapy participated in SMC differentiation. Taken together, these findings indicate that ERCs may be a promising cell source for cellular therapy aimed at modulating SM function in the vagina wall and pelvic floor in order to treat POP.

\section{Introduction}

Pelvic organ prolapse (POP) is a highly prevalent health condition for women in the reproductive and menopausal years. The lifetime risk of any primary surgery for POP is $12.6 \%$ (1). POP occurs as a result of the loss of the normal support and suspension normally provided by the ligaments, endopelvic fascia and levator ani muscle which leads to the descent of one or more of the following: the anterior or posterior vaginal wall, the vaginal apex or the uterus (2). Anterior vaginal wall prolapse (cystocele), with an overall prevalence of $33.8 \%$, is the most common form of POP (3). Current treatment options for POP, and specifically for vaginal wall prolapse, include pelvic floor muscle training, the use of pessaries, and surgery including native tissue repair and those with mesh. To achieve improved anatomical outcomes and overcome the high failure rate following conventional repair, synthetic mesh has been used since the late 1990s $(4,5)$. However, severe complications were increasingly reported $(6,7)$, prompting the FDA to issue two public health notices warning against mesh use $(7,8)$. Cell-based therapy, using stem cells for the regeneration of human tissue to restore or establish normal function, offers a novel approach $(9,10)$.

Smooth muscle (SM) is an integral part of the vaginal wall and endopelvic structures that support the pelvic viscera; a deficiency of vaginal SM will lead to inability to maintain the structural and functional integrity of vaginal support and consequently pelvic floor support (11). Studies have documented decreases in the fractional area as well as structural and biochemical abnormalities in the vaginal SM of patients with POP $(12,13)$. In addition, alterations in the vaginal SM contractile and regulatory proteins have been reported $(14,15)$. Therefore, SM may be a target for cellular therapy. The repair of impaired smooth muscle cells (SMCs) may promote muscle regeneration in the vaginal wall and endopelvic structures, thereby improving POP such that there is no need for further surgery (10). 
Stem cells termed endometrial regenerative cells (ERCs) refer to a population of mesenchymal-like stem cells isolated from human menstrual blood. Preclinical and clinical trials have demonstrated the therapeutic potency of ERCs for a range of clinical applications (16-19). The collection of ERCs utilizes body waste, and thus, they are easy to obtain with minimal inconvenience. ERCs are readily expandable in culture and lack immunogenicity (17). They possess in vitro pluripotency; cultured under the appropriate conditions, they may differentiate into nine different cell lineages from three germ layers $(20,21)$. The myogenic differentiation of ERCs was demonstrated by coculture with rat cardiomyocytes (22); however, the direct differentiation of ERCs into SMCs has not yet been reported, to the best of our knowledge. In the present study, we examined the role of transforming growth factor $\beta 1$ (TGF- $\beta 1$ ) in inducing the differentiation of human ERCs into SMCs as well as the possible signaling pathways involved, to suggest a potential cell-based approach for the management of POP.

\section{Materials and methods}

Cell isolation and culture. The research proposal for human menstrual blood collection was approved by the Ethics Committee of Harbin Medical University, and informed written consent was obtained from each patient. The investigations were conducted according to the principles expressed in the Declaration of Helsinki. Thirty females aged 20-30 were enrolled. The collection of $5 \mathrm{ml}$ menstrual blood was performed during the first few days of the menstrual cycle with a urine cup, and then transferred into a 'collection tube' containing $0.1 \mathrm{ml}$ amphotericin $\mathrm{B}, 0.1 \mathrm{ml}$ penicillin/streptomycin $(\mathrm{P} / \mathrm{S})$ and $0.1 \mathrm{ml}$

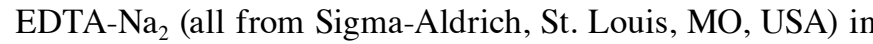
$5 \mathrm{ml}$ phosphate-buffered saline (PBS). Mononuclear cells were isolated by Ficoll-Paque (Sigma-Aldrich) density gradient centrifugation according to the manufacturer's instructions. The cells were subsequently cultured in a T-25 flask containing Dulbecco's modified Eagle's medium/F-12 (DMEM/F-12; Invitrogen, Carlsbad, CA, USA) supplemented with $1 \% \mathrm{P} / \mathrm{S}$, $1 \%$ amphotericin $\mathrm{B}$ and $1 \%$ glutamine (Sigma-Aldrich), and $10 \%$ fetal bovine serum (FBS; Invitrogen) (complete DMEM, cDMEM). The medium was replaced the next day. Once the cells reached $80-90 \%$ confluence, the adherent cells were detached with trypsin (Sigma-Aldrich); and subcultured at a denisty of $1.5 \times 10^{5}$ cells in a T25 flask. The cells were passaged twice a week. The morphology of the cultured cells was examined under a phase contrast microscope (AX 70; Olympus, Tokyo, Japan).

Flow cytometric analysis. The ERCs were stained and labeled with the following specific anti-human antibodies: CD73-fluorescein isothiocyanate (FITC; 344016), CD90-FITC (328108), CD34-FITC (343604), CD45-FITC (368508), CD146-phycoerythrin (PE; 361006) and STRO-1-PE (340106) (BioLegend, San Diego, CA, USA), and detected by flow cytometric analysis. Briefly, the cells were trypsinized and $1.0 \times 10^{6}$ cells were washed and re-suspended in ice-chilled PBS containing $1 \%$ bovine serum albumin (BSA; Invitrogen). Fluorochrome-conjugated antibodies were added at concentrations recommended by the respective manufacturer, and incubated for $30 \mathrm{~min}$ in the dark. The cells were then washed twice in staining buffer, and analyzed under a flow cytometer (LSRFortessa; BD Biosciences, Franklin Lakes, NJ, USA).

SM cell differentiation. To induce SMC differentiation, ERCs were seeded in 6-well tissue culture plates at a density of $4 \times 10^{4}$ cells/well in serum-free medium until they reached $30-40 \%$ confluence. The cells were then cultured with the 'SM inducing medium' which contained cDMEM supplemented with TGF- $\beta 1$ (Sigma-Aldrich) at different concentrations $(0.1$, $0.5,1$ and $5 \mathrm{ng} / \mathrm{ml}$ ) for different periods of time. The medium was replaced every three days.

Transmission electron microscopy (TEM). The ERCs were centrifuged at 2,000 $\mathrm{x}$ g for $5 \mathrm{~min}$ and the pellets were fixed with $2.5 \%$ glutaraldehyde (Sigma-Aldrich) in PBS buffer ( $\mathrm{pH}$ 7.2) at room temperature for $2 \mathrm{~h}$. After several rinses with PBS, the cells were post-fixed with $1 \%$ osmium tetroxide (Sigma-Aldrich) for $1 \mathrm{~h}$ at $4^{\circ} \mathrm{C}$, dehydrated in a graded series of acetone, and embedded in Epon 812. Ultrathin sections were cut (50-70 $\mathrm{nm}$ thick), and then double-stained with uranyl acetate and lead citrate (both from Amresco, Solon, OH, USA) prior to examination under a transmission electron microscope (H-7650; Hitachi, Tokyo, Japan) operating at $80.0 \mathrm{kV}$.

Western blot analysis. The cultured ERCs were washed twice with pre-cooled PBS, followed by protein extraction using RIPA buffer. Protein concentrations were measured using a bicinchoninic acid (BCA) protein assay kit (Sigma-Aldrich). An automated capillary-based Simple Western system (Simon; ProteinSimple, Santa Clara, CA, USA), which allows more accurate and reproducible assessment of protein levels compared with the traditional system, was used in order to quantify the protein level of SMC markers and Smads, according to the manufacturer's instructions. Briefly, the cell lysate samples were mixed with Fluorescent Standard/4X Master Mix (ProteinSimple) at a ratio of 1:3, and then heated for denaturation. The samples, blocking reagent, primary antibodies, HRP-conjugated secondary antibodies, chemiluminescent substrate, and separation and stacking matrices were dispensed into a 384-well plate (ProteinSimple). After loading the plate, the separation electrophoresis and immunodetection occurred automatically. Primary antibodies for the target proteins included rabbit antihuman $\alpha$-smooth muscle actin [ $\alpha$-SMA; actin, alpha 2, smooth muscle, aorta (ACTA2); 14395-1-AP; Proteintech, Rosemont, IL, USA], calponin 1 (CNN1; 13938-1-AP; Proteintech), Smad2 (12570-1-AP; Proteintech), Smad3 (25494-1-AP; Proteintech), phospho-Smad2 (p-Smad2; sc-135644; Santa Cruz Biotechnology, Inc., Dallas, TX, USA) and phospho-Smad3 antibodies (p-Smad3; sc-130218; Santa Cruz Biotechnology, Inc.); goat anti-rabbit IgG (A27036; Molecular Probes, Eugene, OR, USA) was used as the secondary antibody. GAPDH was used as the control. All antibodies were diluted in antibody diluent (ProteinSimple) with a 1:50 dilution. Luminol (Sigma-Aldrich) and peroxide were then added. The resulting chemiluminescent signal was captured using a charge-coupled device (CCD) camera (Simon), and the signal intensities were quantified and analyzed using Compass software (ProteinSimple).

RT-PCR and quantitative PCR ( $q P C R)$. Total RNA from the cultured cells was extracted using a high pure RNA isolation 
Table I. Primer sequences for RT-PCR and quantitative PCR.

\begin{tabular}{|c|c|c|}
\hline Gene (NCBI ID) & Primer sequence & Product size (bp) \\
\hline $\begin{array}{l}\text { ACTA2 } \\
(\mathrm{NM} \text {-001613.2) }\end{array}$ & $\begin{array}{l}\text { Sense: } \\
\text { 5'-CCTTGAGAAGAGTTACGAGTTGC-3' } \\
\text { Antisense: 5'-ATGATGCTGTTGTAGGTGGTTT-3' }\end{array}$ & 144 \\
\hline $\begin{array}{l}\text { CNN1 } \\
(\text { NM_001299.4) }\end{array}$ & $\begin{array}{l}\text { Sense: } \quad \text { 5'-AACCACCACGCACACAACTACTA-3' } \\
\text { Antisense: 5'-TGCTCTCTCCAAACTCTAACCCT-3' }\end{array}$ & 187 \\
\hline $\begin{array}{l}\text { TAGLN } \\
(\text { NM_003186.3) }\end{array}$ & $\begin{array}{l}\text { Sense: } \\
\text { 5'-GGTCTTCAAGCAGATGGAGCAG-3' } \\
\text { Antisense: 5'-TTGCCTTCAAAGAGGTCAACAGT-3' }\end{array}$ & 105 \\
\hline $\begin{array}{l}\text { ALK1 } \\
(\mathrm{NM} 001077401.1)\end{array}$ & $\begin{array}{l}\text { Sense: } \quad \text { 5'-AAACCCCTCTGCCCGACTCAC-3' } \\
\text { Antisense: 5'-CCAGCACACACCACACTCACACTAC-3' }\end{array}$ & 196 \\
\hline $\begin{array}{l}\text { ALK5 } \\
(\mathrm{NM} 004612.2)\end{array}$ & $\begin{array}{l}\text { Sense: } \\
\text { 5'-GACAACGTCAGGTTCTGGCTCAG-3' } \\
\text { Antisense: 5'-TCCTCTCCAAACTTCTCCAAATCG-3' }\end{array}$ & 115 \\
\hline $\begin{array}{l}\text { TGFBR2 } \\
(\mathrm{NM} \text {-001024847.2) }\end{array}$ & $\begin{array}{l}\text { Sense: } \\
\text { 5'-AAGATTCCTGAAGACGGCTCCCTA-3' } \\
\text { Antisense: 5'-CCTGCTGCTGTTGTTTCTGCTTATC-3' }\end{array}$ & 199 \\
\hline $\begin{array}{l}\text { Smad2 } \\
(\text { NM_001003652.3) }\end{array}$ & $\begin{array}{l}\text { Sense: } \quad \text { 5'-TGAAAGGGTGGGGAGCAGAATA-3' } \\
\text { Antisense: 5'-GAGCAACGCACTGAAGGGGAT-3' }\end{array}$ & 136 \\
\hline $\begin{array}{l}\text { Smad3 } \\
(\text { NM_001145102.1) }\end{array}$ & $\begin{array}{l}\text { Sense: } \\
\text { 5'-GAGTGAAGATGGAGAAACCAGTGAC-3' } \\
\text { Antisense: 5'-GTAGTAGGAGATGGAGCACCAGAAG-3' }\end{array}$ & 160 \\
\hline
\end{tabular}

kit (Roche Applied Science, Indianapolis, IN, USA) according to the manufacturer's instructions. One microgram of total RNA was used to make cDNA in a volume of $20 \mu \mathrm{l}$ using the Transcriptor First Strand cDNA Synthesis kit (Roche Applied Science). The resulting cDNA was subjected to PCR analysis using a PCR system (T3000; Biometra, Göttingen, Germany), and qPCR was performed using the SYBR Premix Ex Taq II mix (Takara Biotechnology Co., Ltd., Dalian, China) in a LightCycler 480 Real-Time PCR detection system (Roche Applied Science). $\beta$-actin (ACTB) served as the internal control. The sequences of the forward and reverse primers for amplifying the SMC markers [ACTA2, CNN1 and transgelin $(T A G L N)]$, TGF- $\beta 1$ family receptors [ALK1, ALK5 and transforming growth factor, beta receptor $(T G F B R) 2]$ and Smads (Smad2 and Smad3) are presented in Table I.

Immunocytofluorescence. The cells cultured on sterile coverslips in six-well plates were fixed with $4 \%$ paraformaldehyde for $20 \mathrm{~min}$ at room temperature, permeabilized with $0.1 \%$ Triton $\mathrm{X}-100$ in PBS (pH 7.4) for $15 \mathrm{~min}$ and blocked with 3\% BSA in PBS (pH 7.4) for 20 min. They were then incubated with monoclonal primary antibodies against $\alpha$-SMA (mouse $\operatorname{IgG}, 1: 100$ ) and calponin (rabbit IgG, 1:100) (both from Cell Signaling Technology, Inc., Danvers, MA, USA) in $1 \%$ BSA overnight at $4^{\circ} \mathrm{C}$. Excessive antibody was removed which was followed by incubation with a secondary antibody (FITC-conjugated goat anti-mouse antibody, PE-conjugated goat anti-rabbit antibody, 1:1000; Molecular Probes) at $37^{\circ} \mathrm{C}$ for $1 \mathrm{~h}$ in the dark. The cell nuclei were stained with 4',6-diamidino-2-phenylindole (DAPI; 1:500; Sigma-Aldrich). Then, the slides were washed with PBS and visualized using a fluorescence microscope (BX51; Olympus).

Statistical analysis. All experiments were performed at least in triplicate. Data processing and statistical analysis were performed using Microsoft Excel and GraphPad Prism software. Data are presented as the means \pm standard deviation (SD). Statistical analysis was performed using a Student's t-test or one-way analysis of variance followed by a Bonferroni's multiple-comparison post hoc test to determine differences between the groups. A P-value $<0.05$ was considered to indicate a statistically significant difference.

\section{Results}

Isolation, culture and characterization of ERCs. Single, small, compact cells were revealed 1-2 days after initial seeding; some small colony-like morphology was observed. Within an additional 3-6 days, these cells formed more large colonies, and then stretched into an outgrowth of adherent cells with a fibroblast-like short spindle-shaped morphology upon the completion of 9-12 days of culture (Fig. 1A). Flow cytometric analysis revealed that the majority of ERCs showed strong expression levels for mesenchymal stem cell (MSC) markers CD73 (94.8\%), CD90 (91.5\%), and CD146 (79.3\%), and were negative for the hematopoietic stem cell markers CD34 (2.02\%), and CD45 (2.42\%). In addition, the MSC marker STRO-1 (1.46\%) was negatively expressed (Fig. 1B).

TGF- $\beta 1$ induces the differentiation of ERCs into SMCs. To examine the TGF- $\beta 1$-induced SM differentiation of ERCs and to optimize the induction conditions, the ERCs were cultured with the inducing medium and different concentrations of TGF- $\beta 1$ for different periods of time. SMC-specific marker expression was evaluated by automated western blot analysis performed on Simon, a Simple Western system. Simple Western is a gel-free, blot-free, capillary-based, automated technique. This rapid procedure allows the more accurate, stable and reproducible assessment of protein levels, and greatly reduces the variability caused by the labor-intensive and time-consuming manual 
A
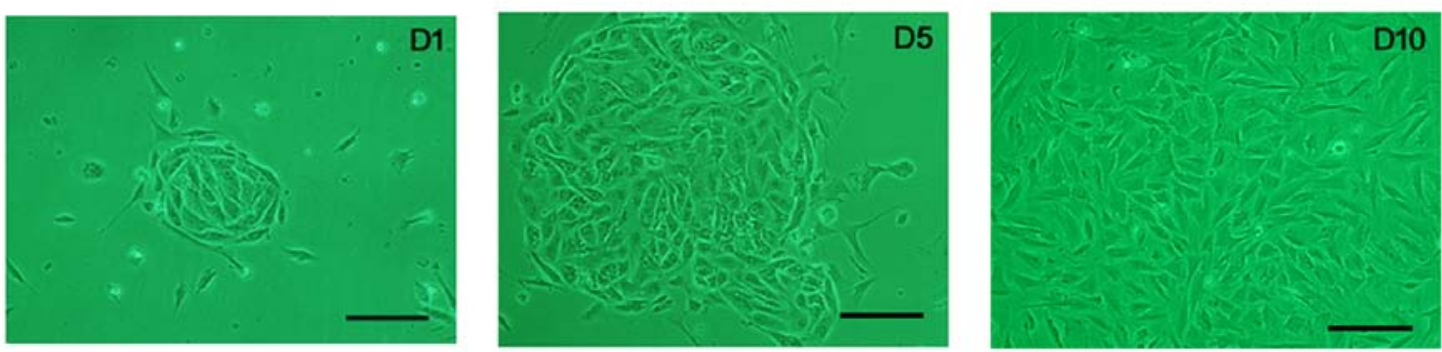

B
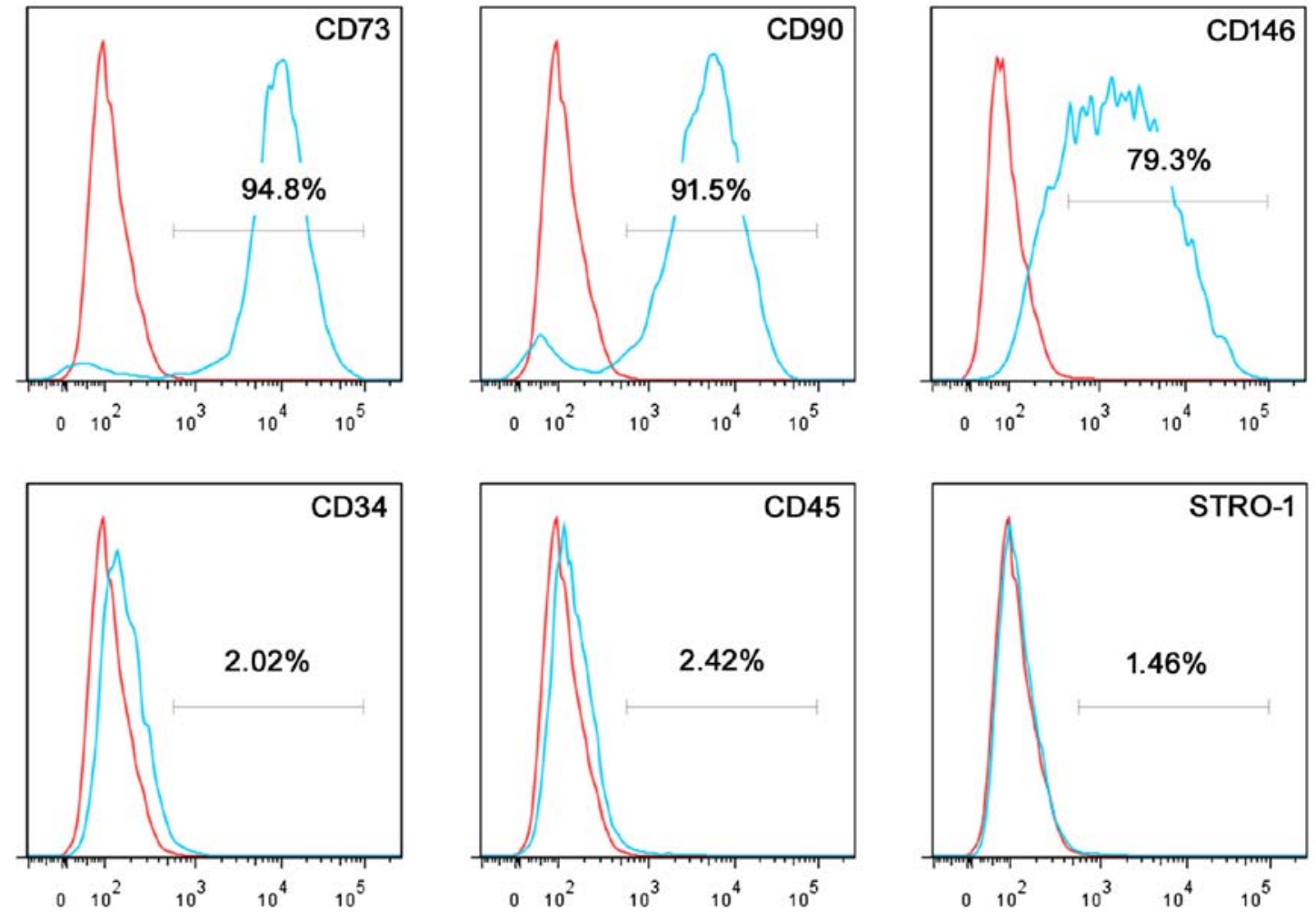

Figure 1. Characterization of the cells derived from menstrual blood. (A) Phase contrast image of cultured endometrial regenerative cells (ERCs). Single, small, compact cells were revealed on day 1, and small colony-like morphology was observed. Larger colonies were observed on day 5.10 days after initial seeding, an outgrowth of adherent cells with a fibroblast-like short spindle-shaped morphology was observed. Scale bar, $200 \mu \mathrm{m}$. (B) Phenotyping of ERCs by flow cytometry. The majority of ERCs were strongly positive for mesenchymal stem cell (MSC) markers except for STRO-1, and negative for hematopoietic stem cell markers.

processes of the traditional western blot assay (23-28). The image generated by Simple Western analysis is quite different from the conventional one. Chemiluminescence signals were collected using a CCD camera, and the collected signal intensity was subsequently processed, converted to an electropherogram, and integrated using the Compass software included on Simon (23). As shown in the gel-like image of Simple Western analysis (Fig. 2), at various concentrations of TGF- $\beta 1$ (0.1, $0.5,1$ and $5 \mathrm{ng} / \mathrm{ml}$ ), the protein levels of $\alpha$-SMA and calponin significantly increased; among the different concentrations, $1 \mathrm{ng} / \mathrm{ml}$ produced the greatest SM differentiation $(\mathrm{P}<0.05)$ (Fig. 2A). Thus, from the viewpoint of marker expression, we considered that $1 \mathrm{ng} / \mathrm{ml}$ TGF- $\beta 1$ performed most efficiently. The fluorescent intensity of the SMC markers increased in a timedependent manner. As shown in Fig. 2B, three days after the addition of TGF- $\beta 1, \alpha$-SMA and calponin became detectable; they increased on the 7th day, and then remained at a relative stable level on the 9th day (the longest time we examined), suggesting that 7 days may be the most efficient duration for the induction. Therefore, we selected a TGF- $\beta 1$ concentration of $1 \mathrm{ng} / \mathrm{ml}$ and an incubation period of 7 days for the subsequent experiments. As we are seeking an ideal cell source for cellular therapy, we then examined whether the induced cells display a stable phenotype after passaging. After 7 days of induction, the ERCs were passaged and cultured in TGF- $\beta 1$-free cDMEM; SMC markers were then examined by western blot analysis. As shown in Fig. 2B, the cells continued to express SMC markers after one passage (the 10th day) without significant changes in the expression level $(\mathrm{P}>0.05)$. Taken together, these data demonstrated that TGF- $\beta 1$ was necessary and sufficient for the induction of an independent and long-lasting differentiation of ERCs into the SMC phenotype, and it occurred in a dose and time-dependent manner.

Immunostaining revealed that $\alpha$-SMA and calponin were positively expressed on the cells after 7 days of incubation in the presence of TGF- $\beta 1$ (Fig. 3).

To characterize the induced cells at the genetic level, we examined the expression of several common markers before 
A

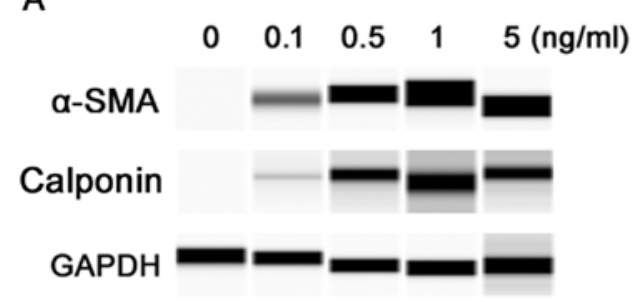

a-SMA

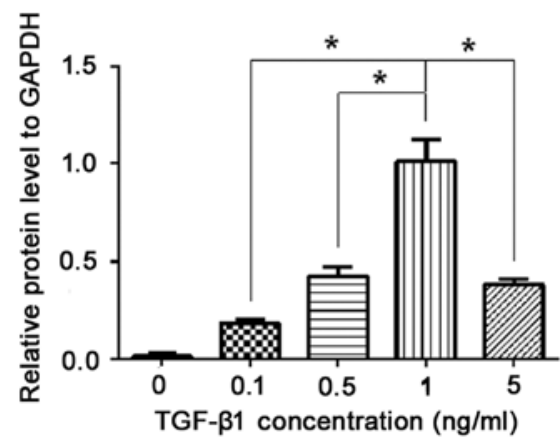

Calponin

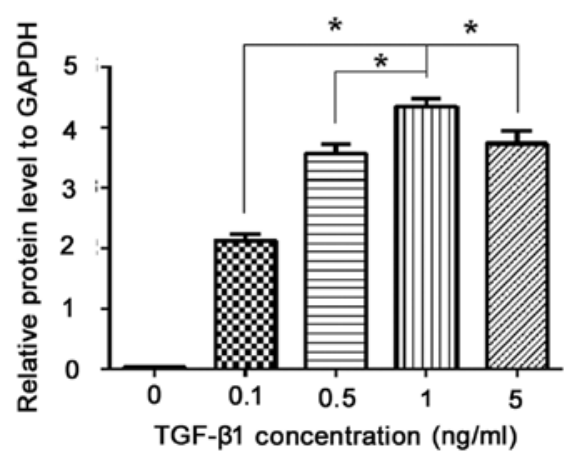

B
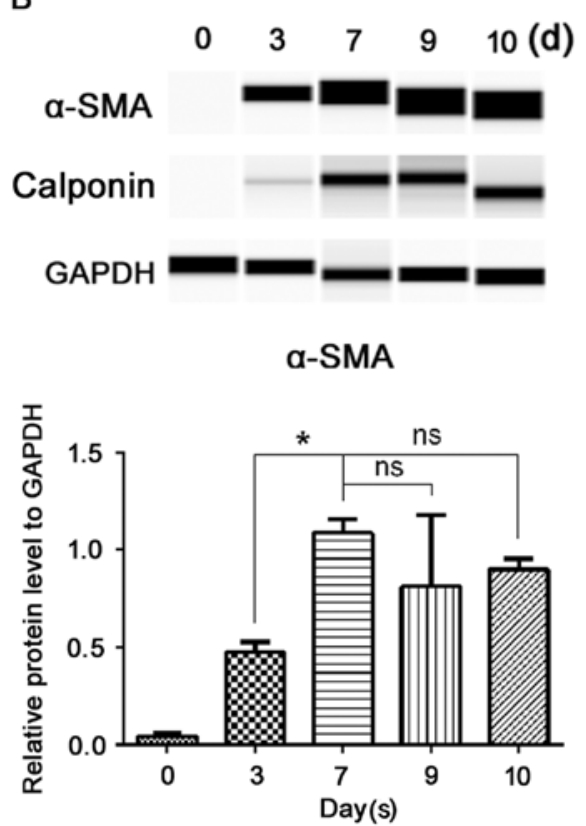

Calponin

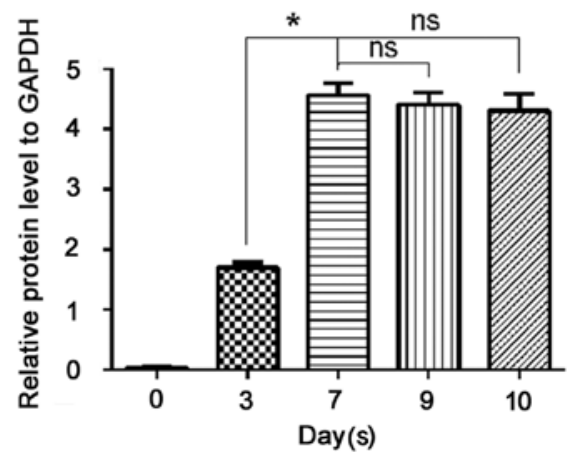

Figure 2. Simple Western analysis of smooth muscle cell (SMC) markers. (A) SMC marker $\alpha$-smooth muscle actin ( $\alpha$-SMA) and calponin (CNN1) were detectable following treatment with transforming growth factor $\beta 1$ (TGF- $\beta 1$ ). Among the different selected concentrations, $1 \mathrm{ng} / \mathrm{ml} \mathrm{TGF}-\beta 1 \mathrm{performed}$ most efficiently in terms of SMC marker expression. (B) Following culture of the ERCs in induction medium (TGF- $\beta 1,1 \mathrm{ng} / \mathrm{ml}$ ) over different periods of time (0, 3, 7,9 days), the SMC markers were most effectively expressed over 7 days. ERCs after the 7 -day induction were passaged and cultured in TGF- $\beta 1$-free cDMEM, SMC markers were positively expressed on the 10 th day, without significant changes in expression level within 7 days. ${ }^{*} \mathrm{P}<0.05$.

and after the induction by semiquantitative RT-PCR. As seen in Fig. 4, TGF- $\beta 1$ induced the expression of ACTA2, $C N N 1$ and $S M 22 \alpha(T A G L N)$ expression. These data further suggest that the induction of $\alpha$-SMA and calponin detected by western blot analysis and immunocytofluorescence were not an isolated phenomenon, but part of the differentiation process into the SMC lineage.

Morphologically, after 7 days of treatment, the cultured cells changed from a short spindle shape to a large, spindle shape (Fig. 5A). Ultrastructure was revealed by TEM. Prior to the induction, the ERCs contained free polyribosome, profiles of rough endoplasmic reticulum and a number of mitochondria. Following the addition of TGF- $\beta 1$, the cells exhibited bundles of thin filaments including 'dense body' like structures (Fig. 5B), which are representative of typical ultrastructural characteristics of SMCs.

Signaling pathway involved in the TGF- $\beta 1$-induced differentiation of ERCs into SMCs. TGF- $\beta$ family members signal through transmembrane type I and type II serine/threonine kinase receptors (TGFBR1 and TGFBR2) and intracellular Smad transcriptional effector proteins (45). To examine whether TGF- $\beta$ signaling components are present in ERCs, the gene expression of TGFBR1/ALK1, ALK5 and TGFBR2 were examined by RT-PCR. ALK5 and TGFBR2 were positively expressed in the ERCs, and the expression level did not alter after TGF- $\beta 1$ involvement $(\mathrm{P}>0.05)$ (Fig. $4 \mathrm{~A}$ and B). Negative expression of ALK1 (Fig. 4A) demonstrated that the ERCs we obtained were not of endothelial origin. TGF signaling is predominantly transduced by the Smads; Smad2 and Smad3 have shown to play crucial roles in SMC differentiation. Gene expression analysis by RT-PCR and qPCR (Fig. 4A and B) revealed that both Smad2 and Smad3 were expressed in the ERCs prior to TGF- $\beta 1$ involvement, and no significant differences were revealed following the induction $(\mathrm{P}>0.05)$. Thus, it appears that ERCs contain all of the components necessary for transducing the TGF signal from the cell surface to the nucleus. 

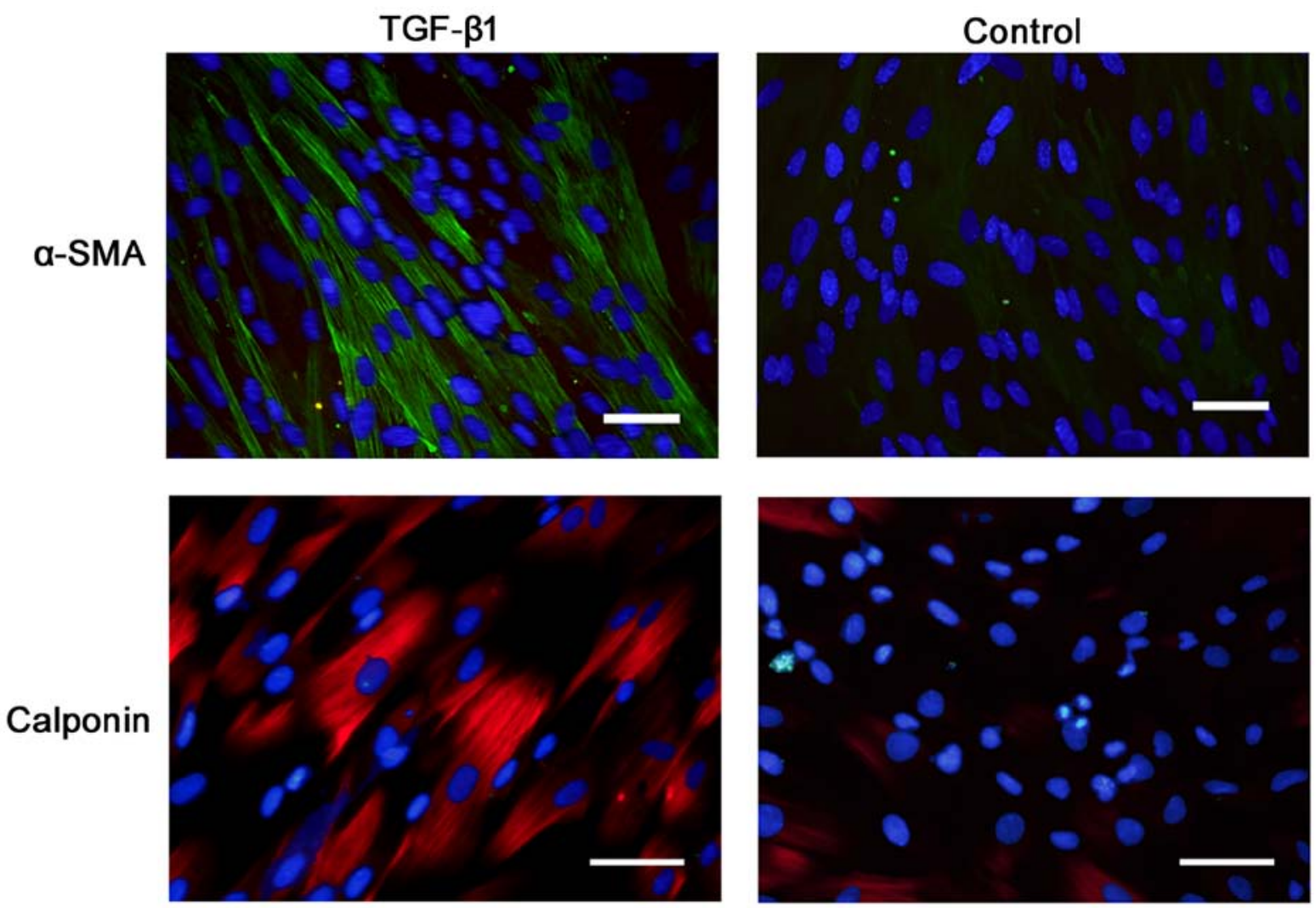

Figure 3. Immunofluorescence analysis of smooth muscle cell (SMC) markers. $\alpha$-smooth muscle actin ( $\alpha$-SMA) and calponin (CNN1) were positively expressed following treatment with transforming growth factor $\beta 1$ (TGF- $\beta 1$ ). Scale bar, $50 \mu \mathrm{m}$.

A

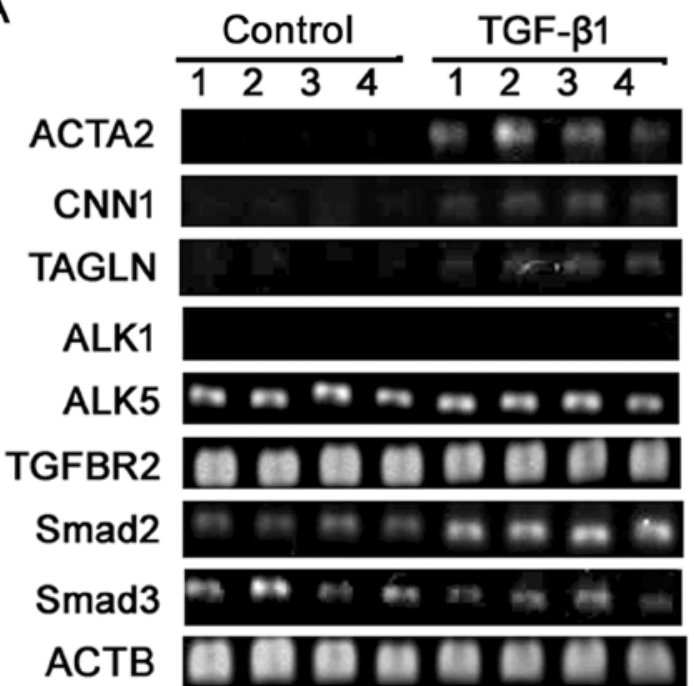

B

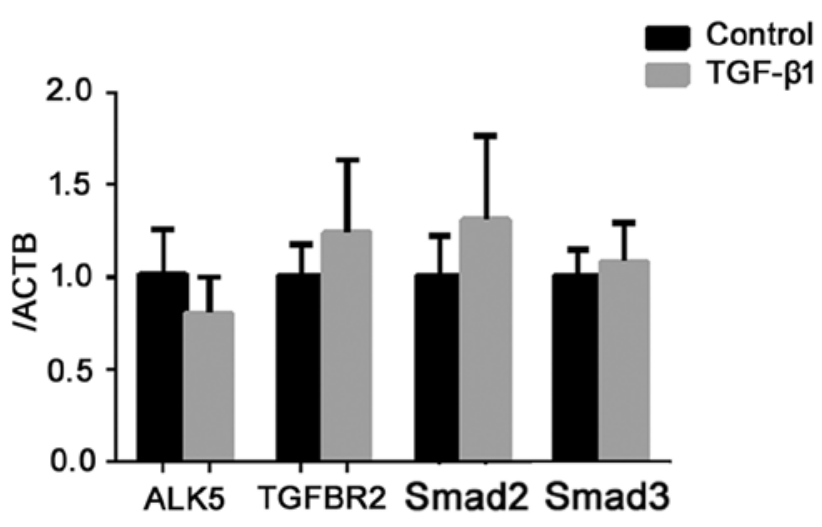

Figure 4. RT-PCR and quantitative PCR analysis of smooth muscle cell (SMC) marker genes and genes along the transforming growth factor $\beta 1$ (TGF- $\beta 1$ )-Smad pathway. (A) RT-PCR analysis of SMC marker genes and the TGF- $\beta 1$ pathway related genes. The SMC marker genes ACTA2, CNN1 and TAGLN were positively expressed following the induction. Genes along the TGF- $\beta 1$-Smad pathway (ALK5, TGFRB2, Smad2 and Smad3) were positively expressed in endometrial regenerative cells (ERCs). (B) Quantitative PCR analysis of ALK5, TGFRB2, Smad2 and Smad3 expression. No significant differences were revealed at the gene expression level before and after the induction $(\mathrm{P}>0.05)$.

To determine whether TGF- $\beta 1$ signals through Smad2 and Smad3 in ERCs, we performed Simple Western analysis of Smad2, Smad3, p-Smad2 and p-Smad3 (Fig. 6). Treated with the inducing medium for various periods of time, the protein levels of Smad2 and Smad3 slightly altered; however, these differences were not statistically significant $(\mathrm{P}>0.05)$.
P-Smad2 and p-Smad3 were negatively expressed before TGF- $\beta 1$ involvement, and they both became detectable on the third day following the addition of TGF- $\beta 1$, increased on the 7th day, and levels were sustained till the 9th day. This was the same as the time course for the induction of $\alpha$-SMA and calponin presented above. These data, at least in part, 
A

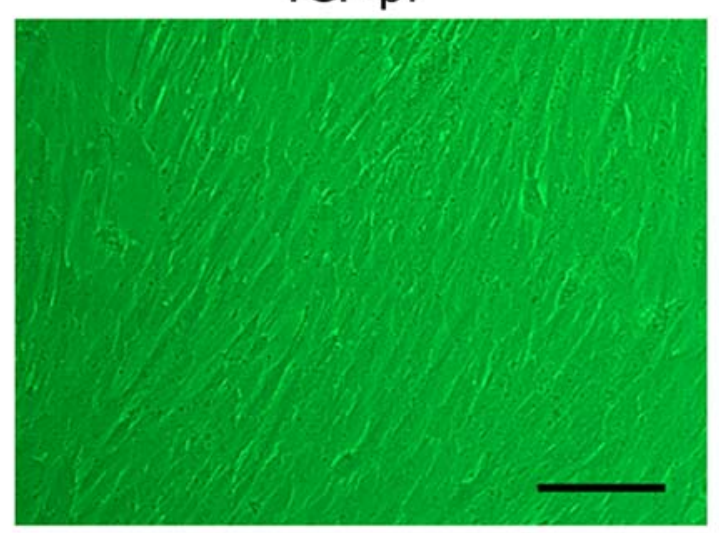

B

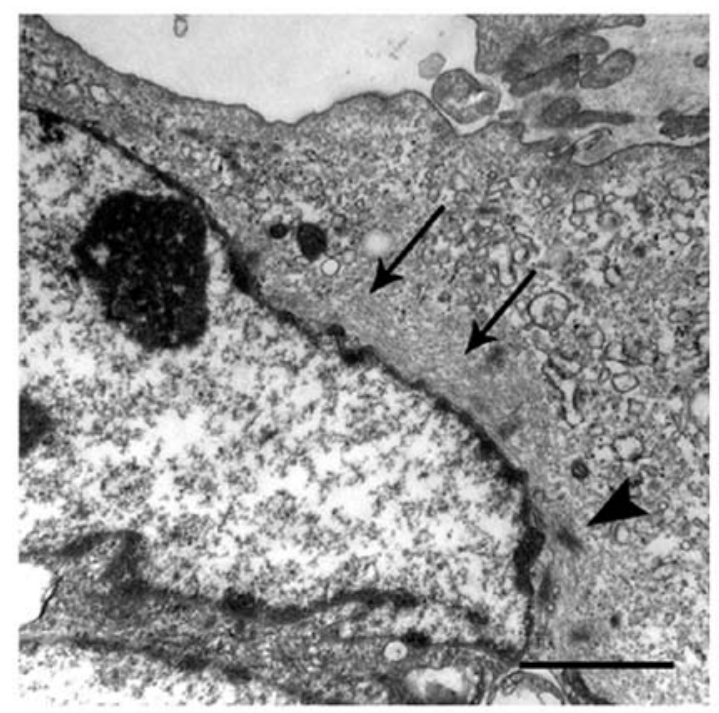

\section{Control}
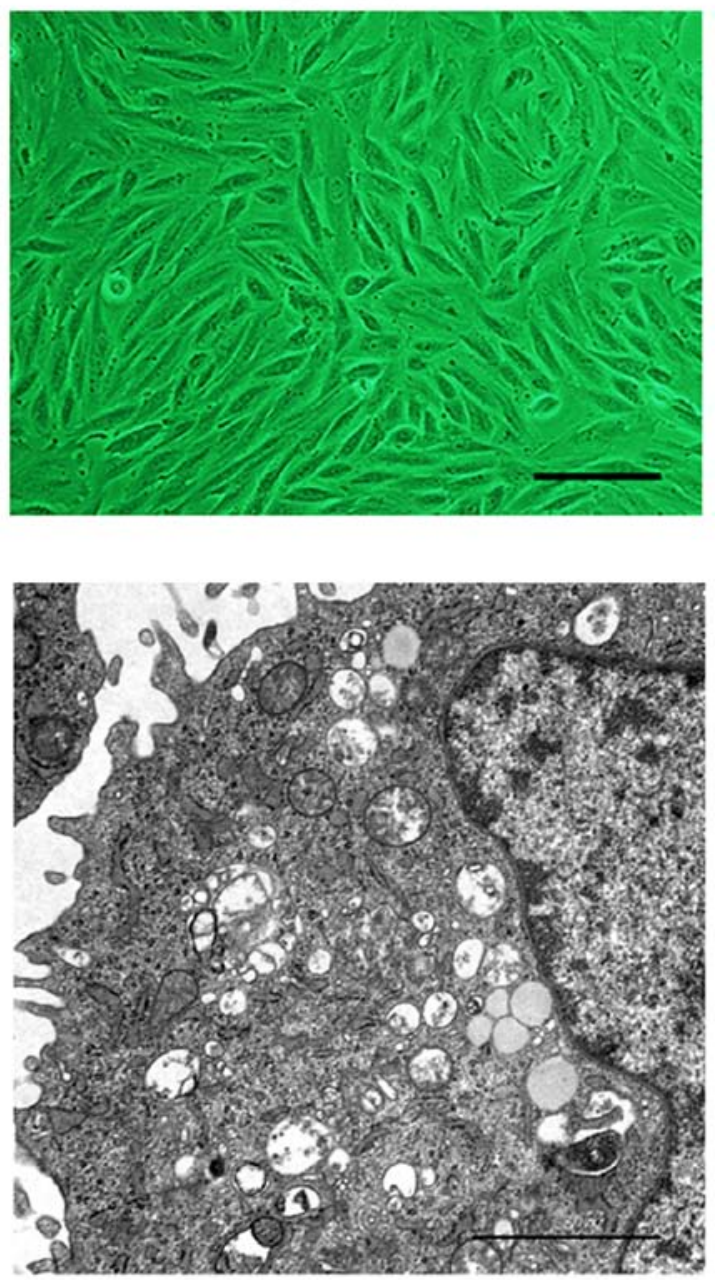

Figure 5. Morphology of endometrial regenerative cells (ERCs) and the induced cells. (A) Phase contrast image of ERCs and the induced cells. After 7 days of treatment with the transforming growth factor $\beta 1$ (TGF- $\beta 1$ )-based medium, the cultured cells changed from a short spindle shape to a large, spindle shape. (B) Transmission electron microscope images of ERCs (right panel) and the induced cells (left panel). When the induction was finished, the cells showed typical ultrastructural features of smooth muscle cells (SMCs). Black arrows indicate thin filaments; black arrowhead indicates dense bodies. Scale bars, (A) 200 and (B) $2 \mu \mathrm{m}$.

suggested that the TGF- $\beta 1$-induced SM differentiation of ERCs was Smad dependent.

\section{Discussion}

Over the last few decades, MSCs from different origins have become an attractive cell source for regenerative medicine and tissue engineering, such as those derived from bone marrow (bmMSCs), adipose tissue, umbilical cord blood and amniotic fluid among others (29-33). The potential applications of MSCs in the management of different diseases are enormous. However, the process of harvesting these cells is often an invasive procedure, which limits their application.

The endometrium - the highly regenerative lining of the uterus is an accessible source of MSCs (20,21,34-37). Viable MSC-like cells have been isolated non-invasively from human menstrual blood using the plastic adherence method (20), the manner used to obtain bmMSCs, and these adherent cells were described as ERCs. Previous studies have demonstrated that ERCs fulfills all the key properties for an ideal cell source for cellular therapy $(20,38)$. A comparative profiling of ERCs and bmMSCs showed similar but not identical profiles (39); ERCs proliferated faster, and an evaluation of cytokine secretion suggested that ERCs may be more suitable for different tissue engineering purposes (39).

In the present study, ERCs were obtained from menstrual blood. Phenotypically, the ERCs shared some markers with MSCs; however, they also possessed unique features, which matched the findings of previous studies $(20,21)$. The ERCs possessed the capacity to proliferate extensively and with clonogenic activity. In addition, we evaluated the proliferation ability of ERCs among different age groups (data not shown). Women aged 20-30 were enrolled in the present study, as females of this age are most active in terms of reproductive ability. To induce the differentiation of stem cells into SMCs, various protocols with different inducing factors have been suggested (40-43), and TGF- $\beta 1$ is one of the factors mentioned most frequently. The TGF- $\beta$ family of cytokines has been implicated in a number of cellular processes, such as proliferation, differentiation and apoptosis (44-46). The Smad pathway is a classic route for the TGF- $\beta$-induced SMC differentiation. The procedures involved include the binding of ligands to TGFBR2 on the cell surface, the recruitment and phosphorylation of TGFBR1, and the activation of downstream signals (45-47). 

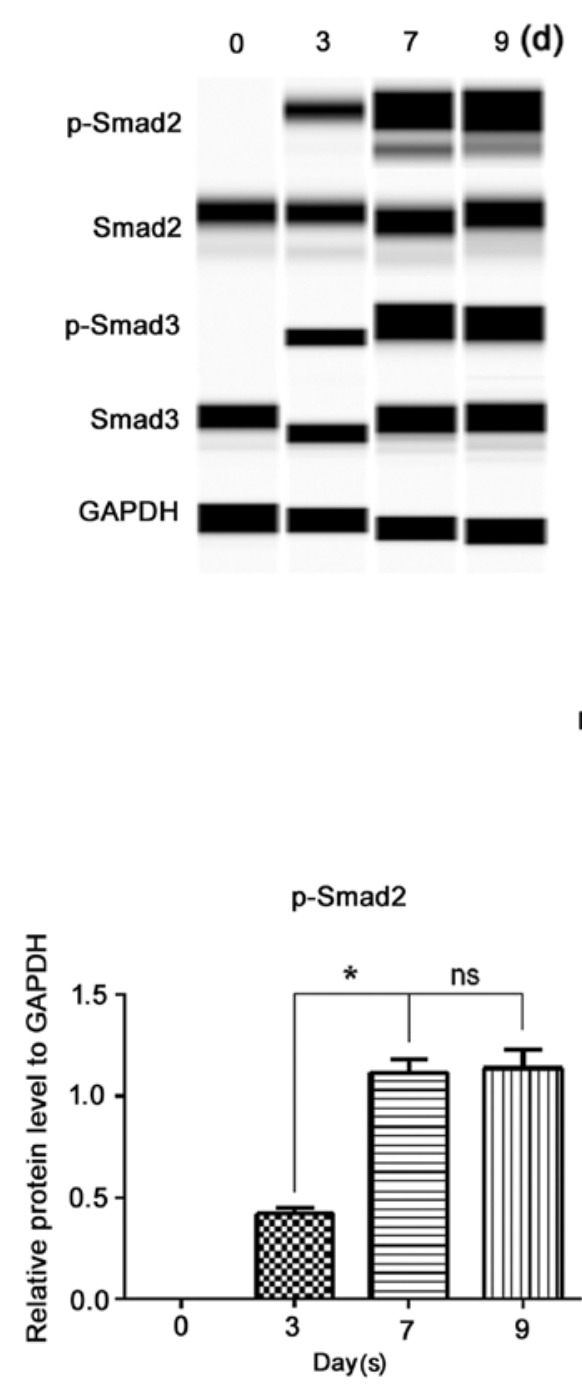

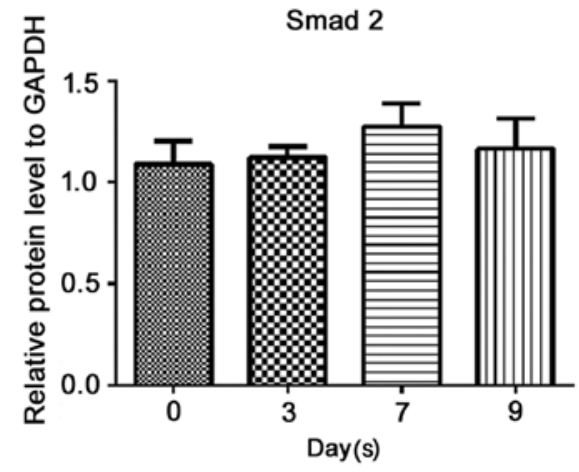

p-Smad3

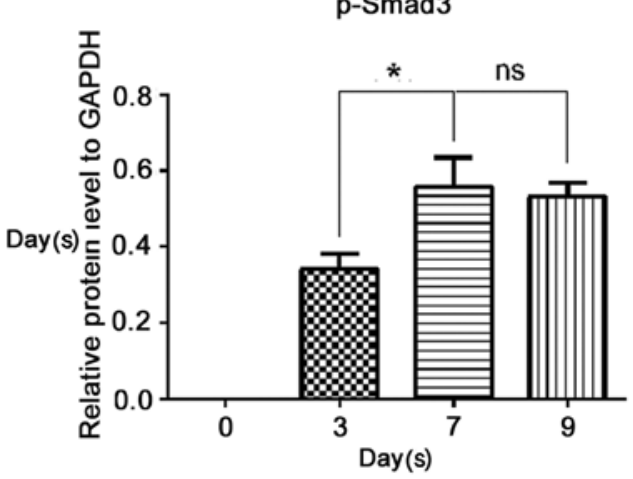

Smad3

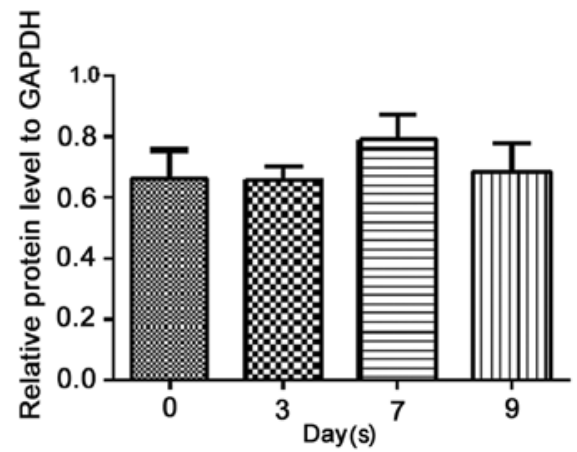

Figure 6. Simple Western analysis of the Smads and phospho-Smads (p-Smads). Treated for different culture times, the protein levels of Smad2 and Smad3 slightly altered, but no statistically significant differences was revealed $(\mathrm{P}>0.05)$. P-Smad2 and $\mathrm{p}$-Smad3 were negatively expressed before transforming growth factor $\beta 1$ (TGF- $\beta 1$ ) involvement, and they both became detectable after the induction and changed with time.

TGF- $\beta$ signaled exclusively through the TGFBR2, and used two types of TGFBR1 - ALK5 and ALK1, and ALK1 expression was largely restricted to endothelial cells (47). Stem cells of different origins have been shown to differentiate into SMCs in response to TGF- $\beta 1$ given singly or in combination with other reagents $(41,48-51)$. In this study, we selected TGF- $\beta 1$ as a single inducing factor. The results indicated that TGF- $\beta 1$ may be a feasible and efficient reagent capable of inducing primary SMC differention of ERCs. Compared with protocols using multiple factors, TGF- $\beta 1$ given singly is more easily accessible and cost-effective. Therefore, this protocol has the potential to be the primary choice for induction. The establishment of this basic protocol is fundamental to further study of the induction medium and the SMC differentiation of ERCs. Furthermore, we aimed to elucidate whether the effects of TGF- $\beta 1$ occurred through this pathway in ERCs and if so, whether there were any preferences or defects on the receptors and/or downstream signals. The results indicated that ERCs possessed all the components of the Smad pathway, and TGF- $\beta 1$ signaled predominantly, if not exclusively, through the 'TGFBR2/ ALK5/Smad2 and Smad3' pathway in ERCs.

A surgical approach is often indicated for the treatment of POP, particularly since the introduction of synthetic mesh. However, the use of mesh is limited by mesh-related complications including infection, pain, vaginal fibrosis and erosion $(6-8,52)$. Furthermore, the long-term durability and safety of synthetic mesh remain unknown. Cell-based therapy may provide an attractive alternative alone or as an adjunct to surgical reconstructive procedures for POP $(9,10)$. Stem cells have been principally applied in the development of tissue engineered repair biomaterials to treat POP, which may replace the use of synthetic mesh (53-55). The addition of autologous stem cells has been proved to improve the biomechanical properties of scaffolds, and potentially achieve long-term mechanical integrity (53-56). Cellular therapy has also emerged as a promising approach for stress urinary incontinence (57-60). The cells have been administered intravenously or by local injection into the urethra or periurethral areas (61-64). Great interest has been 
focused on adipose-derived stem cells $(54,55,59,61,62)$. ERCs are a readily available source of adult stem cells. Preclinical and clinical studies of ERCs have shown promising therapeutic results in several diseases $(17,19,65)$; however, the value of ERCs in POP has not yet been explored, to the best of our knowledge. This study demonstrated that ERCs were induced to differentiate into SMCs with TGF- $\beta 1$. By repairing the impaired SMCs in the vaginal wall and endopelvic structures, ERCs are promising candidates for improving the treatment of patients with POP. The approaches used with stem cells of other origins may be applied to ERCs.

There are limitations to the autologous treatment of POP using ERCs. Vaginal contact may increase the risk of ERC infections; however, following treatment with antibiotics and antimycotics, no associated infections were revealed. A certain portion of patients with POP are older adults with no further possibility of collecting ERCs. However, if ERCs are proved to be of high therapeutic value, we may collect ERCs from patients of a younger age for storage in case of future need.

In conclusion, TGF- $\beta 1$ is highly efficient at inducing SMC differentiation of ERCsinvitro, and the 'TGFBR2/ALK5/Smad2 and Smad3' pathway is involved. ERCs are a potentially promising cell source for cell-based therapeutic strategies to treat POP. Preliminary establishment of the induction protocol is of great value for the functional assessment of the induced SMCs in vitro and in vivo. It is also a helpful tool for elucidating the role of SMCs in the pathogenesis of POP.

\section{Acknowledgements}

We thank Shuliang Wu, Liang Sun, Xinlei Li, Yafang Zhang and Zunjiang Xie for their outstanding technical support.

\section{References}

1. Wu JM, Matthews CA, Conover MM, Pate V and Jonsson Funk M: Lifetime risk of stress urinary incontinence or pelvic organ prolapse surgery. Obstet Gynecol 123: 1201-1206, 2014.

2. Haylen BT, de Ridder D, Freeman RM, Swift SE, Berghmans B, Lee J, Monga A, Petri E, Rizk DE, Sand PK and Schaer GN: An International Urogynecological Association (IUGA)/International Continence Society (ICS) joint report on the terminology for female pelvic floor dysfunction. Neurourol Urodyn 29: 4-20, 2010.

3. Hendrix SL, Clark A, Nygaard I, Aragaki A, Barnabei V and McTiernan A: Pelvic organ prolapse in the Women's Health Initiative: gravity and gravidity. Am J Obstet Gynecol 186: 1160-1166, 2002.

4. Olsen ALSV, Smith VJ, Bergstrom JO, Colling JC and Clark AL: Epidemiology of surgically managed pelvic organ prolapse and urinary incontinence. Obstet Gynecol 89: 501-506, 1997.

5. Maher C, Feiner B, Baessler K and Schmid C: Surgical management of pelvic organ prolapse in women. Cochrane Database Syst Rev 4: CD004014, 2013.

6. Baessler K, Hewson AD, Tunn R, Schuessler B and Maher CF: Severe mesh complications following intravaginal slingplasty. Obstet Gynecol 106: 713-716, 2005.

7. Nguyen JN, Jakus-Waldman SM, Walter AJ, White T and Menefee SA: Perioperative complications and reoperations after incontinence and prolapse surgeries using prosthetic implants. Obstet Gynecol 119: 539-546, 2012.

8. Liang R, Abramowitch S, Knight K, Palcsey S, Nolfi A, Feola A, Stein S and Moalli PA: Vaginal degeneration following implantation of synthetic mesh with increased stiffness. BJOG 120 : 233-243, 2013

9. Ho MH, Heydarkhan S, Vernet D, Kovanecz I, Ferrini MG, Bhatia NN and Gonzalez-Cadavid NF: Stimulating vaginal repair in rats through skeletal muscle-derived stem cells seeded on small intestinal submucosal scaffolds. Obstet Gynecol 114: 300-309, 2009.
10. Boennelycke M, Gras S and Lose G: Tissue engineering as a potential alternative or adjunct to surgical reconstruction in treating pelvic organ prolapse. Int Urogynecol J Pelvic Floor Dysfunct 24: 741-747, 2013.

11. Northington GM, Basha M, Arya LA, Wein AJ and Chacko S: Contractile response of human anterior vaginal muscularis in women with and without pelvic organ prolapse. Reprod Sci 18: 296-303, 2011.

12. Boreham MK, Wai CY, Miller RT, Schaffer JI and Word RA: Morphometric properties of the posterior vaginal wall in women with pelvic organ prolapse. Am J Obstet Gynecol 187: 1501-1508, discussion 1508-1509, 2002.

13. Inal HA, Kaplan PB, Usta U, Taştekin E, Aybatli A and Tokuc B: Neuromuscular morphometry of the vaginal wall in women with anterior vaginal wall prolapse. Neurourol Urodyn 29: 458-463, 2010.

14. Bortolini MA, Shynlova O, Drutz HP, Castro RA, Girão MJ, Lye S and Alarab M: Expression of genes encoding smooth muscle contractile proteins in vaginal tissue of women with and without pelvic organ prolapse. Neurourol Urodyn 31: 109-114, 2012.

15. Meijerink AM, van Rijssel RH and van der Linden PJ: Tissue composition of the vaginal wall in women with pelvic organ prolapse. Gynecol Obstet Invest 75: 21-27, 2013.

16. Murphy MP, Wang H, Patel AN, Kambhampati S, Angle N, Chan K, Marleau AM, Pyszniak A, Carrier E, Ichim TE and Riordan NH: Allogeneic endometrial regenerative cells: an 'Off the shelf solution' for critical limb ischemia? J Transl Med 6: 45, 2008.

17. Zhong Z, Patel AN, Ichim TE, Riordan NH, Wang H, Min WP, Woods EJ, Reid M, Mansilla E, Marin GH, et al: Feasibility investigation of allogeneic endometrial regenerative cells. J Transl Med 7: 15, 2009.

18. Ichim TE, Alexandrescu DT, Solano F, Lara F, Campion RN, Paris E, Woods EJ, Murphy MP, Dasanu CA, Patel AN, et al: Mesenchymal stem cells as anti-inflammatories: implications for treatment of Duchenne muscular dystrophy. Cell Immunol 260: 75-82, 2010.

19. Bockeria L, Bogin V, Bockeria O, Le T, Alekyan B, Woods EJ, Brown AA, Ichim TE and Patel AN: Endometrial regenerative cells for treatment of heart failure: a new stem cell enters the clinic. J Transl Med 11: 56, 2013.

20. Meng X, Ichim TE, Zhong J, Rogers A, Yin Z, Jackson J, Wang H, Ge W, Bogin V, Chan KW, et al: Endometrial regenerative cells: a novel stem cell population. J Transl Med 5: 57, 2007.

21. Patel AN,Park E, Kuzman M,Benetti F, Silva FJ and Allickson JG: Multipotent menstrual blood stromal stem cells: isolation, characterization, and differentiation. Cell Transplant 17: 303-311, 2008.

22. Hida N, Nishiyama N, Miyoshi S, Kira S, Segawa K, Uyama T, Mori T, Miyado K, Ikegami Y, Cui C, et al: Novel cardiac precursor-like cells from human menstrual blood-derived mesenchymal cells. Stem Cells 26: 1695-1704, 2008.

23. Rustandi RR, Loughney JW, Hamm M, Hamm C, Lancaster C, Mach A and Ha S: Qualitative and quantitative evaluation of Simon $^{\mathrm{TM}}$, a new CE-based automated western blot system as applied to vaccine development. Electrophoresis 23: 2790-2797, 2012.

24. Kohn EA, Yang YA, Du Z, Nagano Y, Van Schyndle CM, Herrmann MA, Heldman M, Chen JQ, Stuelten CH, Flanders KC and Wakefield LM: Biological responses to TGF- $\beta$ in the mammary epithelium show a complex dependency on Smad3 gene dosage with important implications for tumor progression. Mol Cancer Res 10: 1389-1399, 2012.

25. Chen JQ, Heldman MR, Herrmann MA, Kedei N, Woo W, Blumberg PM and Goldsmith PK: Absolute quantitation of endogenous proteins with precision and accuracy using a capillary Western system. Anal Biochem 442: 97-103, 2013.

26. Bakhsheshian J, Hall MD, Robey RW, Herrmann MA, Chen JQ, Bates SE and Gottesman MM: Overlapping substrate and inhibitor specificity of human and murine ABCG2. Drug Metab Dispos 41: 1805-1812, 2013.

27. Klein BY, Tamir H, Hirschberg DL, Glickstein SB and Welch MG: Oxytocin modulates mTORC1 pathway in the gut. Biochem Biophys Res Commun 432: 466-471, 2013.

28. Xu D, Mane S and Sosic Z: Characterization of a biopharmaceutical protein and evaluation of its purification process using automated capillary western blot. Electrophoresis 36: 363-370, 2015.

29. Satija NK, Singh VK, Verma YK, Gupta P, Sharma S, Afrin F, Sharma M, Sharma P, Tripathi RP and Gurudutta GU: Mesenchymal stem cell-based therapy: a new paradigm in regenerative medicine. J Cell Mol Med 13: 4385-4402, 2009. 
30. Mosna F, Sensebé L and Krampera M: Human bone marrow and adipose tissue mesenchymal stem cells: a user's guide. Stem Cells Dev 19: 1449-1470, 2010.

31. Nishimatsu H, Suzuki E, Kumano S, Nomiya A, Liu M, Kume H and Homma Y: Adrenomedullin mediates adipose tissue-derived stem cell-induced restoration of erectile function in diabetic rats. J Sex Med 9: 482-493, 2012.

32. Ghionzoli M, Repele A, Sartiani L, Costanzi G, Parenti A, Spinelli V, David AL, Garriboli M, Totonelli G, Tian J, et al: Human amniotic fluid stem cell differentiation along smooth muscle lineage. FASEB J 27: 4853-4865, 2013.

33. Sharma RR, Pollock K, Hubel A and McKenna D: Mesenchymal stem or stromal cells: a review of clinical applications and manufacturing practices. Transfusion 54: 1418-1437, 2014

34. Kato K, Yoshimoto M, Kato K, Adachi S, Yamayoshi A, Arima T, Asanoma K, Kyo S, Nakahata T and Wake N: Characterization of side-population cells in human normal endometrium. Hum Reprod 22: 1214-1223, 2007.

35. Schwab KE and Gargett CE: Co-expression of two perivascular cell markers isolates mesenchymal stem-like cells from human endometrium. Hum Reprod 22: 2903-2911, 2007.

36. Cervelló I, Gil-Sanchis C, Mas A, Delgado-Rosas F, Martínez-Conejero JA, Galán A, Martínez-Romero A, Martínez S, Navarro I, Ferro J, et al: Human endometrial side population cells exhibit genotypic, phenotypic and functional features of somatic stem cells. PLoS One 5: e10964, 2010.

37. Cervelló I, Mas A, Gil-Sanchis C, Peris L, Faus A, Saunders PT, Critchley $\mathrm{HO}$ and Simón C: Reconstruction of endometrium from human endometrial side population cell lines. PLoS One 6 : e21221, 2011

38. Ulrich D, Muralitharan R and Gargett CE: Toward the use of endometrial and menstrual blood mesenchymal stem cells for cell-based therapies. Expert Opin Biol Ther 13: 1387-1400, 2013

39. Wang H, Jin P, Sabatino M, Ren J, Civini S, Bogin V, Ichim TE and Stroncek DF: Comparison of endometrial regenerative cells and bone marrow stromal cells. J Transl Med 10: 207, 2012.

40. Lindskog H, Athley E, Larsson E, Lundin S, Hellström M and Lindahl P: New insights to vascular smooth muscle cell and pericyte differentiation of mouse embryonic stem cells in vitro. Arterioscler Thromb Vasc Biol 26: 1457-1464, 2006.

41. Narita Y, Yamawaki A, Kagami H, Ueda M and Ueda Y: Effects of transforming growth factor-beta 1 and ascorbic acid on differentiation of human bone-marrow-derived mesenchymal stem cells into smooth muscle cell lineage. Cell Tissue Res 333 449-459, 2008.

42. Pepe AE, Xiao Q, Zampetaki A, Zhang Z, Kobayashi A, Hu Y and Xu Q: Crucial role of nrf3 in smooth muscle cell differentiation from stem cells. Circ Res 106: 870-879, 2010.

43. Park JS, Chu JS, Tsou AD, Diop R, Tang Z, Wang A and Li S: The effect of matrix stiffness on the differentiation of mesenchymal stem cells in response to TGF- $\beta$. Biomaterials 32: 3921-3930, 2011

44. Valcourt U, Kowanetz M, Niimi H, Heldin CH, Moustakas A: TGF-beta and the Smad signaling pathway support transcriptomic reprogramming during epithelial-mesenchymal cell transition. Mol Biol Cell 16: 1987-2002, 2005.

45. Santibañez JF, Quintanilla $M$ and Bernabeu C: TGF- $\beta /$ TGF- $\beta$ receptor system and its role in physiological and pathological conditions. Clin Sci (Lond) 121: 233-251, 2011.

46. Tang Y, Yang X, Friesel RE, Vary CP, Liaw L: Mechanisms of TGF- $\beta$-induced differentiation in human vascular smooth muscle cells. J Vasc Res 48: 485-494, 2011.

47. Bobik A: Transforming growth factor-betas and vascular disorders. Arterioscler Thromb Vasc Biol 26: 1712-1720, 2006.

48. Zhao Z, Yu H, Xiao F, Wang X, Yang S and Li S: Differentiation of adipose-derived stem cells promotes regeneration of smooth muscle for ureteral tissue engineering. J Surg Res 178: 55-62, 2012.
49. Chen $\mathrm{S}$ and Lechleider RJ: Transforming growth factor-beta-induced differentiation of smooth muscle from a neural crest stem cell line. Circ Res 94: 1195-1202, 2004.

50. Chou MT, Chang SN, Ke C, Chang HI, Sung ML, Kuo HC and Chen $\mathrm{CN}$ : The proliferation and differentiation of placental-derived multipotent cells into smooth muscle cells on fibrillar collagen. Biomaterials 31: 4367-4375, 2010.

51. Wang D, Park JS, Chu JS, Krakowski A, Luo K, Chen DJ and Li S: Proteomic profiling of bone marrow mesenchymal stem cells upon transforming growth factor $\beta 1$ stimulation. J Biol Chem 279: 43725-43734, 2004.

52. Jia X, Glazener C, Mowatt G, MacLennan G, Bain C, Fraser C and Burr J: Efficacy and safety of using mesh or grafts in surgery for anterior and/or posterior vaginal wall prolapse: systematic review and meta-analysis. BJOG 115: 1350-1361, 2008.

53. Roman S, Mangera A, Osman NI, Bullock AJ, Chapple CR and MacNeil S: Developing a tissue engineered repair material for treatment of stress urinary incontinence and pelvic organ prolapse-which cell source? Neurourol Urodyn 33: 531-537, 2014.

54. Aboushwareb T, McKenzie P, Wezel F, Southgate J and Badlani G: Is tissue engineering and biomaterials the future for lower urinary tract dysfunction (LUTD)/pelvic organ prolapse (POP)? Neurourol Urodyn 30: 755-782, 2011.

55. Hung MJ, Wen MC, Huang YT, Chen GD, Chou MM and Yang VC: Fascia tissue engineering with human adipose-derived stem cells in a murine model: implications for pelvic floor reconstruction. J Formos Med Assoc 113: 704-715, 2014.

56. Su K, Edwards SL, Tan KS, White JF, Kandel S, Ramshaw JA, Gargett CE and Werkmeister JA: Induction of endometrial mesenchymal stem cells into tissue-forming cells suitable for fascial repair. Acta Biomater 10: 5012-5020, 2014.

57. Smaldone MC and Chancellor MB: Muscle derived stem cell therapy for stress urinary incontinence. World J Urol 26: 327-332, 2008.

58. Lin CS and Lue TF: Stem cell therapy for stress urinary incontinence: a critical review. Stem Cells Dev 21: 834-843, 2012.

59. Roche R, Festy F and Fritel X: Stem cells for stress urinary incontinence: the adipose promise. J Cell Mol Med 14: 135-142, 2010.

60. Nikolavasky D, Stangel-Wójcikiewicz K, Stec M and Chancellor MB: Stem cell therapy: a future treatment of stress urinary incontinence. Semin Reprod Med 29: 61-70, 2011.

61. Lin G, Wang G, Banie L, Ning H, Shindel AW, Fandel TM, Lue TF and Lin CS: Treatment of stress urinary incontinence with adipose tissue-derived stem cells. Cytotherapy 12: 88-95, 2010.

62. Shi LB, Cai HX, Chen LK, Wu Y, Zhu SA, Gong XN, Xia YX, Ouyang HW and Zou XH: Tissue engineered bulking agent with adipose-derived stem cells and silk fibroin microspheres for the treatment of intrinsic urethral sphincter deficiency. Biomaterials 35: 1519-1530, 2014.

63. Dissaranan C, Cruz MA, Kiedrowski MJ, Balog BM, Gill BC, Penn MS, Goldman HB and Damaser MS: Rat mesenchymal stem cell secretome promotes elastogenesis and facilitates recovery from simulated childbirth injury. Cell Transplant 23: 1395-1406, 2014.

64. Cruz M, Dissaranan C, Cotleur A, Kiedrowski M, Penn M and Damaser M: Pelvic organ distribution of mesenchymal stem cells injected intravenously after simulated childbirth injury in female rats. Obstet Gynecol Int 2012: 612946, 2012.

65. Borlongan CV, Kaneko Y, Maki M, Yu SJ, Ali M, Allickson JG, Sanberg CD, Kuzmin-Nichols N and Sanberg PR: Menstrual blood cells display stem cell-like phenotypic markers and exert neuroprotection following transplantation in experimental stroke. Stem Cells Dev 19: 439-452, 2010. 